\title{
Synthesis and Characterization of Bifunctional Organic-Glasses Based on Diphenylhydrazone and Barbituric Acid Derivative for Photorefractive Application
}

\author{
Sang Ho Lee, ${ }^{\ddagger}$ Chil Sung Choi, ${ }^{,}$Nakjoong Kim, ${ }^{\dagger}$ Dong Hoon Choi, ${ }^{\ddagger}$ and Ki Hong Park* \\ Optoelectronics Material Research Center, KIST, P.O. Box 131, Seoul 136-791, Korea \\ 'Department of Chemistry, Hanvang Universin, Seoul 133-791, Korea \\ :Polmer \& Fiber Materials Engineering, Kunghee Chiversin, Younginn, Gyungki-do 449-701. Korea \\ Received Mav 27, 2003
}

\begin{abstract}
A series of amorphous molecules that possess both photoconductive and electro-optic properties was ș'nthesized in order to investigate photorefractive properties of bifunctional organic-glasses. Diethylaminobenzaldehyde-diphenyllhydrazone was covalently attached to 5-(4-diethylamino-benzylidene)-1.3-dimethylpyrimidine-2.4.6-trione through a flexible alkyl chain (3,4.5.6 and 10 carbons) containing two ether linkages. The longer linkage not only lowered the glass transition temperature $\left(\mathrm{T}_{g}\right)$ of the molecules. but also allowed faster orientation of the chromophore. To examine the photorefractive properties. a $50 \mu \mathrm{m}$-thick film was prepared from the mixture of a bifunctional molecule. butyl benzỵl phthalate. and $\mathbf{C}_{601}$. The photoconductivity of this composite was as high as $8.01 \times 10^{-13} \mathrm{~S} / \mathrm{cm}$ at $60 \mathrm{~V} / \mu \mathrm{m}$, and the maximum diffraction efficiency $\left(\eta_{\mathrm{mok}}\right)$ of $50 \mu \mathrm{m}$-thick film was about $5 \%$ at $80 \mathrm{~V} / \mu \mathrm{m}$.
\end{abstract}

Key Words : Photorefractive, Diphenyl hydrazone. Bifunctional, Organic-glasses, Amorphous molecule

\section{Introduction}

Photorefractive effect refers to a spatial modulation of the refractive index in a material due to the light-induced redistribution of charge. ${ }^{1.2}$ Photorefractivity $(\mathrm{PR})$ combines a photoconductivity with a nonlinear optical (NLO) response to produce a reversible light-induced modulation of the refractive index. ${ }^{3}$ In general. photorefractive materials are prepared by combining all required functional moieties to form multifunctional organic-glasses or more commonly in host-guest composite.

Among many organic photorefractive materials reported to date composite polymers such as poly(siloxane carbazole) or poly (vinyl carbazole) doped with NLO chromophore have been extensively studied due to their remarkable photorefractive properties. ${ }^{+7}$ This host-guest sy'stem. however. often lacked the device stability arising from the limited compatibility between nonpolar photoconducting polymer and polar NLO chromophore. ${ }^{+}$The phase separation of composite seriously limited the photorefractive properties and life-time of photorefractive materials.

An important aspect of multifunctional organic-glasses was to improve the long-term stability and to minimize the phase separation of the device comparable with the hostguest system. The amorphous organic-glasses possessed many desirable material properties such as transparency. low crystallization and facile fabrication. Recently. organic photorefractive glasses based on bifunctional molecules. which provide electro-optic property and charge transport in a single molecule. have been reported. ${ }^{8-11}$ In addition to much improved lifetime of device. several low molecular

\footnotetext{
*To whom correspondence should be addressed. e-mail: khopark akjist.re.kT
}

weight organic glasses have shown the excellent photorefractive properties. comparable to the polymeric host-guest composites ${ }^{20}$

In this study, a series of amorphous coupled-molecules was synthesized based on diethylaminobenzaldehydediphenylhydrazone (DEH) and nonlinear optical chromophore. 5-(4-dietlylamino-benzýlidene)-1.3-dimethyl-pyrimidine-2.4.6-trione. A flexible spacer of the alkyl chain with different lengths $(3,4,5.6$ and 10 carbons) was introduced between the photoconducting unit and the electro-optical chromophore unit. which prevented crystallization of molecules and lowered their glass transition temperatures. To characterize the photorefractive performance of the molecule. the composite was characterized by DC photocurrent measurement. transmission ellipsometry method. and degenerate four-wave mixing.

\section{Experimental Section}

Characterization and Measurement. ${ }^{~} \mathrm{H}-\mathrm{NMR}$ spectra were taken by Varian Unityplus NMR Spectroscopy 300 $\mathrm{MHz}$. The UV-vis absorption spectra were recorded using a Jasco V-530 spectrophotometer. The glass transition temperatures $\left(T_{g}\right)$ were determined with a differential scanning calorimeter (DSC). Perkin-Elmer Pyris 1 series. at a heating rate of $10^{\circ} \mathrm{C} / \mathrm{min}$ under nitrogen atmosphere.

The DC photocurrent measurement was performed on about $50 \mu \mathrm{m}$-thick composite film sandwiched between ITO electrodes at a temperature of near $\mathrm{T}_{\mathrm{g}}$. The illuminating beam from $\mathrm{He}-\mathrm{Ne}$ laser $(633 \mathrm{~nm})$ was expanded into the diameter of $6 \mathrm{~mm}$ and its intensity was $13 \mathrm{~mW} / \mathrm{cm}^{2}$.

The electro-optical property of the composite was characterized by the transmission ellipsometric measurement at various electric fields. ${ }^{13}$ The sample tilted by $+45^{\circ}$ and $-45^{\circ}$ 
in air was placed between the polarizer and the analyzer. The birefringence $(\Delta \mathrm{n})$ of the sample was determined from the transmittance of the reading beam passing through crossed polarizers upon the applied electric field.

Diffraction efficiency (n) was measured by a degenerate four-wave mixing method. The experiment was performed near the $\mathrm{T}_{\mathrm{g}}\left(17^{\circ} \mathrm{C}\right)$ of the composite. Two colherent laser beams from $\mathrm{He}-\mathrm{Ne}$ laser were irradiated on the sample in the tilted geometry with the incident angle of $30^{\circ}$ and $60^{\circ}$ with respect to sample nornal. Both of writing beams were spolarized and had the equal intensity of $60 \mathrm{~mW} / \mathrm{cm}^{2}$. A ppolarized counter-propagating beam was used to read out the recorded photorefractive grating. Attenuated reading bean with the intensity of $0.1 \mathrm{~mW} / \mathrm{cm}^{2}$ was used. The internal diffraction efficiency $\left(\eta_{\max }\right)$ of photorefractive material was determined from an equation $\eta_{\text {int }}=\mathrm{I}_{R_{\text {dififfracted }}} / \mathrm{I}_{\mathrm{R} \text { diffracted }}+$ $\mathrm{I}_{\mathrm{R}, \text { transstitted }}$. $^{5}$

Materials. 4-(Dietlylamino)salicylaldehyde, potassium hydroxide. Aliquat 336 , and 1.1-diphenylhydrazine hydrochloride were purchased from the Aldrich Chemical Co. 1,3Dibromopropane. 1.4-dibromobutane, 1,5-dibromopentane. 1,6-dibromohexane. 1,10-dibromodecane were purchased from the Merk-Schuchardt. 1,3-Dimethylbarbituric acid purchased from the Tolyo Kasei Kogyo Co. Ltd was used without further purification.

Synthesis of C3: In a 2 L three-necked flask equipped with a magnetic stirrer and a reflux condenser, $75 \mathrm{~g}(0.388$ $\mathrm{mol}$ ) of 4-(diethylamino)salicylaldehyde. $600 \mathrm{~mL}$ of tetrahydrofuran. $53.6 \mathrm{~g}$ of potassium hydroxide, and several drops of Aliquat ${ }^{3} 336$ were added and stirred at $100^{\circ} \mathrm{C}$. 1.3Dibromopropane (39 $\mathrm{g} / 0.194 \mathrm{~mol})$ was dropped into the mixture. This mixture was reacted at a reflux for 24 hours and then the cooled mixture was poured into cold water. The precipitate was filtered, dried, and purified by recrystallization from ethyl acetate to give $77 \mathrm{~g}(94 \%$ yield $)$ of a desired product as yellow solid (nip $1+3{ }^{\circ} \mathrm{C}$ ): ${ }^{1} \mathrm{H}-\mathrm{NMR}$ (DMSO- $\left.d_{6}\right): \delta(\mathrm{ppm}) 10.03(2 \mathrm{H}, \mathrm{s}) .7 .49(2 \mathrm{H} . \mathrm{d}) .6 .33(2 \mathrm{H}$. d), $6.17(2 \mathrm{H}, \mathrm{s}) .4 .29(4 \mathrm{H} . \mathrm{t}), 3.44(8 \mathrm{H}, \mathrm{m}), 2.27(2 \mathrm{H}, \mathrm{m})$. and $1.11(12 \mathrm{H} . \mathrm{t})$.

The synthetic procedures $(\mathbf{C 4}, \mathbf{C 5}$. C6. and C10) were used as the same method to $\mathbf{C} 3$.

C4: $93 \%$ yield. mp $140^{\circ} \mathrm{C}$ at first heating of DSC: ${ }^{\circ} \mathrm{H}$ NMR $\left(\mathrm{CDCl}_{3}\right): \delta(\mathrm{ppm}) 10.18(2 \mathrm{H} . \mathrm{s}) .7 .72(2 \mathrm{H} . \mathrm{d}), 6.31$ $(2 \mathrm{H}, \mathrm{d}), 6.04(2 \mathrm{H} . \mathrm{s}), 4.14(4 \mathrm{H} . \mathrm{t}), 3.43(8 \mathrm{H}, \mathrm{m}), 2.01(4 \mathrm{H}$. $\mathrm{m})$. and $1.22(12 \mathrm{H}, \mathrm{m})$.

C5: $95 \%$ yield mp $123^{\circ} \mathrm{C}$ at first heating of DSC: ${ }^{1} \mathrm{H}$ NMR $\left(\mathrm{CDCl}_{3}\right): \delta$ (ppm) 10.18 (2H. s). 7.72 (2H. d), 6.28 $(2 \mathrm{H}, \mathrm{d}), 6.03(2 \mathrm{H} . \mathrm{s}), 4.07(4 \mathrm{H} . \mathrm{t}), 3.43(8 \mathrm{H}, \mathrm{m}), 1.94(4 \mathrm{H}$. $\mathrm{m}) .1 .73(2 \mathrm{H} . \mathrm{m})$, and $1.22(12 \mathrm{H} . \mathrm{t})$.

C6: $94 \%$ yield. mp $155^{\circ} \mathrm{C}$ at first heating of DSC: ${ }^{1} \mathrm{H}$ NMR $\left(\mathrm{CDCl}_{3}\right): \delta$ (ppm) 10.19 (2H. s). 7.72 (2H. d), 6.28 $(2 \mathrm{H}, \mathrm{d}), 6.02(2 \mathrm{H} . \mathrm{s}), 4.06(4 \mathrm{H} . \mathrm{t}), 3.43(8 \mathrm{H}, \mathrm{m}), \mathrm{l} .86(4 \mathrm{H}$. m). $1.58(+\mathrm{H} . \mathrm{m})$, and $1.22(12 \mathrm{H} . \mathrm{t})$.

C10: $44 \%$ yield. mp $121{ }^{\circ} \mathrm{C}$ at first heating of DSC: ${ }^{1} \mathrm{H}$ NMR $\left(\mathrm{CDCl}_{3}\right): \delta(\mathrm{ppm}) 10.18$ (2H. s). 7.74 (2H. d), 6.30 $(2 \mathrm{H}, \mathrm{d}), 6.02(2 \mathrm{H} . \mathrm{s}), 4.06(4 \mathrm{H} . \mathrm{t}), 3.48(8 \mathrm{H}, \mathrm{m}), 1.88(2 \mathrm{H}$. $\mathrm{m})$. and $1.48-1.18(26 \mathrm{H} . \mathrm{m})$.
Synthesis of H-C3-ald: Into a flask $100 \mathrm{~mL}$ of ethanol, 4 $\mathrm{g}$ of $\mathbf{C 3}(9.38 \mathrm{mmol})$ was added with stirring at $80^{\circ} \mathrm{C}$. The mixture of 1.1-diphenylhydrazine hydrochloride $2.07 \mathrm{~g}$ $(9.38 \mathrm{mmol})$ and sodium acetate trihydrate $1.91 \mathrm{~g}$ (14.07 mmol) in ethanol were slowly dropped into the above solution and maintained at $80^{\circ} \mathrm{C}$. The mixture was stirred just for 2 hours, and then the cool mixture was evaporated to remove solvent under reduced pressure. This misture was extracted with methylene chloride. and the organic layer was dried over with anhydrous sodium sulfate, and filtered. The condensed product was purified by column chromatograply on silica gel (eluent; ethyl acetate : hexane $=1: 4$ ). The product was obtained as yellow powder $(1.45 \mathrm{~g} .26 \%$ yield, $\mathrm{mp} 124^{\circ} \mathrm{C}$ at first heating of DSC): ${ }^{1} \mathrm{H}-\mathrm{NMR}\left(\mathrm{CDCl}_{2}\right): \delta$ (ppm) $10.18(\mathrm{lH} . \mathrm{s}) .7 .9 \mathrm{l}(\mathrm{lH} . \mathrm{d}) .7 .77(\mathrm{lH}, \mathrm{d}) .7 .38(4 \mathrm{H}$, m). $7.18(4 \mathrm{H} . \mathrm{m}), 7.05(2 \mathrm{H}, \mathrm{m}), 6.38(2 \mathrm{H} . \mathrm{m}) .6 .07(\mathrm{lH}, \mathrm{s})$, 5.98 (lH. s), 4.04 (2H. t). 3.97 (2H. t) $3.44(8 \mathrm{H}, \mathrm{m}), 2.14-$ $2.09(2 \mathrm{H}, \mathrm{m})$, and $1.24-1.19(13 \mathrm{H}, \mathrm{m})$.

The synthetic procedures (H-C4-ald, H-C5-ald, H-C6ald, and $\mathrm{H}$-C10-ald) were used as the same method to $\mathbf{H}$ C3-ald

H-C4-ald: $17 \%$ yield. $\mathrm{mp} 121^{\circ} \mathrm{C}$ at first heating of DSC, ${ }^{1} \mathrm{H}-\mathrm{NMR}\left(\mathrm{CDCl}_{3}\right): \delta(\mathrm{ppm}) 10.18(\mathrm{lH}, \mathrm{s}) .7 .95$ (lH. d). 7.77 (lH. d), $7.38(4 \mathrm{H}, \mathrm{m}) .7 .19(4 \mathrm{H}, \mathrm{m}), 7.09(2 \mathrm{H} . \mathrm{m}), 6.37(2 \mathrm{H}$, m). $6.04(\mathrm{lH} . \mathrm{s}) .5 .99(\mathrm{lH}, \mathrm{s}) .3 .94(4 \mathrm{H} . \mathrm{m}) .3 .47(8 \mathrm{H}, \mathrm{m})$, $1.84-1.75(4 \mathrm{H}, \mathrm{m})$, and $1.24-1.19(13 \mathrm{H}, \mathrm{m})$.

H-C5-ald: $20 \%$ yield. $\mathrm{mp} 128^{\circ} \mathrm{C}$ at first heating of DSC: ${ }^{1} \mathrm{H}-\mathrm{NMR}\left(\mathrm{CDCl}_{3}\right): \delta(\mathrm{ppm}) 10.20(\mathrm{lH}, \mathrm{s}) .7 .94$ (lH. d). 7.75 (lH. d). $7.38(4 \mathrm{H}, \mathrm{m}) .7 .17(4 \mathrm{H}, \mathrm{m}), 7.1 \mathrm{l}(2 \mathrm{H} . \mathrm{m}), 6.35(2 \mathrm{H}$, m). 6.05 (lH. s). $5.87(\mathrm{lH}, \mathrm{s}) .3 .91$ (4H. m). $3.43(8 \mathrm{H}, \mathrm{m})$, $1.80(6 \mathrm{H}, \mathrm{m})$, and $1.21-1.16(13 \mathrm{H}, \mathrm{m})$.

H-C6-ald: $13 \%$ yield. $\mathrm{mp} 98^{\circ} \mathrm{C}$ at first heating of DSC: ${ }^{1} \mathrm{H}-\mathrm{NMR}\left(\mathrm{CDCl}_{3}\right): \delta(\mathrm{ppm}) 10.22(\mathrm{lH}, \mathrm{s}) .7 .93$ (lH. d). 7.75 (1H. d), $7.39(4 \mathrm{H}$, t). 7.20 (4H. d), 7.13 (2H. d), $6.38(2 \mathrm{H}$, m). $6.07(2 \mathrm{H}, \mathrm{d}) .4 .03(2 \mathrm{H} . \mathrm{t}), 3.85(2 \mathrm{H}, \mathrm{t}), 3.47 .3 .34(8 \mathrm{H}$, $\mathrm{m}) .1 .82(2 \mathrm{H} . \mathrm{m}), 1.62(2 \mathrm{H} . \mathrm{m}), 1.45(2 \mathrm{H} . \mathrm{m})$, and $1.31-1.13$ $(15 \mathrm{H}, \mathrm{m})$.

H-C10-ald: $19 \%$ yield. mp $110^{\circ} \mathrm{C}$ at first heating of DSC ${ }^{\mathrm{l}} \mathrm{H}-\mathrm{NMR}(\mathrm{CDCl}) ; \dot{\delta}$ (ppm) 10.22 (lH, s), 7.94 (lH.d), 7.77 (lH. d), $7.40(4 \mathrm{H}, \mathrm{t}) .7 .2 \mathrm{l}(4 \mathrm{H} . \mathrm{d}), 7.14(2 \mathrm{H} . \mathrm{d}), 6.39(2 \mathrm{H}$, m). $6.07(2 \mathrm{H}, \mathrm{d}) .4 .03(2 \mathrm{H} . \mathrm{t}), 3.85(2 \mathrm{H}, \mathrm{t}), 3.47 .3 .34(8 \mathrm{H}$, $\mathrm{m}) .1 .85(2 \mathrm{H} . \mathrm{m}), 1.68(4 \mathrm{H} . \mathrm{m}), 1.46(2 \mathrm{H} . \mathrm{m})$, and $1.35-1.15$ $(17 \mathrm{H}, \mathrm{m})$.

Synthesis of H-C3-B: In a $250-\mathrm{mL}$ two necked flask equipped with a magnetic stirrer and a reflux condenser, $0.85 \mathrm{~g}(1.43 \mathrm{mmol})$ of H-C3-ald. $100 \mathrm{~mL}$ of ethanol. $0.22 \mathrm{~g}$ (1.43 mmol) of 1.3-dimethylbarbituric acid were added and stirred at $80^{\circ} \mathrm{C}$. This mixture was reacted at reflux for 3 hours. And the reaction mixture was then cooled to room temperature, filtered the precipitation which was extracted with ethyl acetate (EA), dried over anhydrous magnesium sulfate, filtered and then evaporated the solvent. This product was purified by column clromatography on silica gel (eluent ethyl acetate : hexane $=1: 2$ ). The product was obtained as red powder $\left(0.39 \mathrm{~g} .37 \%\right.$ yield, $\mathrm{mp} 152^{\circ} \mathrm{C}$ at first heating of DSC): ${ }^{l} \mathrm{H}-\mathrm{NMR}\left(\mathrm{CDCl}_{3}\right)$ : $\delta(\mathrm{ppm}) 9.04$ (lH. s), $8.98(\mathrm{lH}, \mathrm{d})$, 7.82 (lH. d), 7.53 (lH. s), 7.35 (4H. t), 7.16 (4H. m), 7.03 
$(2 \mathrm{H}, \mathrm{t}), 6.39(2 \mathrm{H}, \mathrm{t}), 6.08(1 \mathrm{H}, \mathrm{s}), 6.91(\mathrm{lH}, \mathrm{s}), 4.10(2 \mathrm{H}, \mathrm{t})$. $3.95(2 \mathrm{H}, \mathrm{t}), 3.45-3.31(14 \mathrm{H}, \mathrm{m}), 2.20(2 \mathrm{H}, \mathrm{m})$, and $1.22-$ $1.16(12 \mathrm{H}, \mathrm{m})$.

The synthetic procedures (H-C4-B, H-C5-B, H-C6-B, and $\mathbf{H}-\mathbf{C 1 0 - B}$ ) were used as the same method to H-C3-B.

Synthesis of H-C4-B: $29 \%$ yield, $\mathrm{mp} 125^{\circ} \mathrm{C}$ at first heating of DSC: ${ }^{1} \mathrm{H}-\mathrm{NMR}\left(\mathrm{CDCl}_{3}\right) ; \delta(\mathrm{ppm}) 9.09(1 \mathrm{H}, \mathrm{s})$. $8.96(1 \mathrm{H}, \mathrm{d}) .7 .92(1 \mathrm{H}, \mathrm{d}) .7 .57(1 \mathrm{H}, \mathrm{s}) .7 .39(4 \mathrm{H}, \mathrm{t}), 7.18$ $(6 \mathrm{H}, \mathrm{m}), 6.35(2 \mathrm{H}, \mathrm{d}), 6.05(2 \mathrm{H}, \mathrm{d}), 3.95(4 \mathrm{H}, \mathrm{t}), 3.46(4 \mathrm{H}$. $\mathrm{m}), 3.40-3.37(10 \mathrm{H}, \mathrm{m}), 1.85(4 \mathrm{H}, \mathrm{m})$, and $1.30-1.18(12 \mathrm{H}$. $\mathrm{m})$.

Synthesis of H-C5-B: $40 \%$ yield, mp $140{ }^{\circ} \mathrm{C}$ at first heating of DSC. 'H-NMR ( $\left.\mathrm{CDCl}_{\mathrm{s}}\right)$; $\delta(\mathrm{ppm}) 9.09(1 \mathrm{H}, \mathrm{s})$. $8.94(1 \mathrm{H}, \mathrm{d}) .7 .90(1 \mathrm{H}, \mathrm{d}) .7 .57(1 \mathrm{H}, \mathrm{s}) .7 .36(4 \mathrm{H}, \mathrm{t}), 7.15$ $(6 \mathrm{H}, \mathrm{m}), 6.33(2 \mathrm{H}, \mathrm{d}), 6.01(2 \mathrm{H}, \mathrm{d}), 3.99(2 \mathrm{H}, \mathrm{t}), 3.88(2 \mathrm{H}, \mathrm{t})$. $3.50 \sim 3.30(14 \mathrm{H}, \mathrm{m}), 1.84(2 \mathrm{H}, \mathrm{m}), 1.69(2 \mathrm{H}, \mathrm{m}), 1.64(2 \mathrm{H}$. $\mathrm{m})$, and $1.30-1.18(12 \mathrm{H}, \mathrm{m})$,

Synthesis of H-C6-B: $22 \%$ yield, $m p 126{ }^{\circ} \mathrm{C}$ at first heating of DSC: ${ }^{1} \mathrm{H}-\mathrm{NMR}\left(\mathrm{CDCl}_{3}\right) ; \delta(\mathrm{ppm}) 9.12(1 \mathrm{H}, \mathrm{s})$, $8.94(1 \mathrm{H}, \mathrm{d}) .7 .91(1 \mathrm{H}, \mathrm{d}) .7 .57(1 \mathrm{H}, \mathrm{s}) .7 .39(4 \mathrm{H}, \mathrm{t}), 7.15$ $(6 \mathrm{H}, \mathrm{m}), 6.35(2 \mathrm{H}, \mathrm{d}), 6.05(2 \mathrm{H}, \mathrm{d}), 4.04(2 \mathrm{H}, \mathrm{t}), 3.85(2 \mathrm{H}, \mathrm{t})$. $3.51-3.33(14 \mathrm{H}, \mathrm{m}), 1.86(2 \mathrm{H}, \mathrm{m}), 1.63(2 \mathrm{H}, \mathrm{m}), 1.48(2 \mathrm{H}$, $\mathrm{m})$, and $1.33-1.16(14 \mathrm{H}, \mathrm{m})$,

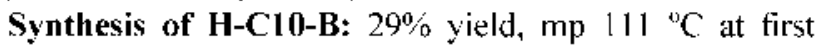
heating of DSC. 'H-NMR $\left(\mathrm{CDCl}_{3}\right)$; $\delta(\mathrm{ppm}) 9.10(1 \mathrm{H}, \mathrm{s})$, $8.98(1 \mathrm{H}, \mathrm{d}), 7.98(1 \mathrm{H}, \mathrm{d}), 7.59(1 \mathrm{H}, \mathrm{s}), 7.43(4 \mathrm{H}, \mathrm{t}), 7.22$ $(8 \mathrm{H}, \mathrm{m}), 6.40(2 \mathrm{H}, \mathrm{d}), 6.10(2 \mathrm{H}, \mathrm{d}), 4.10(2 \mathrm{H}, \mathrm{t}), 3.84(4 \mathrm{H}$, $\mathrm{m}), 3.53-3.37(14 \mathrm{H}, \mathrm{m}), 1.93(4 \mathrm{H}, \mathrm{m})$, and $1.32-1.19(20 \mathrm{H}$. $\mathrm{m})$.

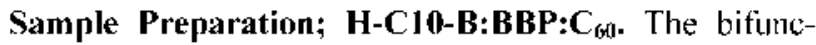
tional molecule (H-C10-B), butyl bemzyl phthalate (BBP) and buckminsterfullerene $\left(C_{(10}\right)$ were dissolved in toluene for casting solution. $\mathrm{C}_{60}$ was added as a sensitizer for the photogeneration in visible region and $\mathbf{B B P}$ was added as a plasticizer for decreasing the glass transition temperature
$\left(T_{p}\right)$ of the sample. The mass ratio of the three constituents was H-C10-B : BBP : $\mathbf{C}_{60}=89: 10: 1$ (wt $\%$ ). The solution was filtered through a $0.2 \mathrm{~mm}$ filter and casted on an indium tin oxide (ITO)-patterned glass plate, dried for 12 hours at ambient temperature and subsequently heated in an oven at $90^{\circ} \mathrm{C}$ for 24 hours to completely remove the residual solvent. Then thick film was softened by placing it on a hot plate at $100{ }^{\circ} \mathrm{C}$ and then it was covered with another ITO coated glass. Teflon spacers with the thickness of $50 \mu \mathrm{m}$ between two ITO glass plates were used to control the film thickness.

\section{Results and Discussion}

We synthesized a series of amorphous molecules with photoconducting unit and nonlinear optic chromophore unit in order to improve the plase stability of photorefractive system. As shown in Scheme 1, the coupled dialdehyde Cn $(\mathrm{n}=3,4,5,6$, and 10$)$ was readily synthesized by condensation of 4-(dietlylamino)salicylaldehyde with dibromoalkyls using potassium hydroxide as a base. The coupled molecules (H-Cn-B) with different lengths of carbon chains (3, 4, 5, 6 and 10 carbons) were successfully synthesized by condensation of 1,1-diphenylhydrazine hydrochloride with $\mathbf{C n}$ to give H-Cn-ald, and followed by condensation of barbituric acid derivatives with the corresponding H-Cn-ald to give H-Cn-B. The DEH is well known as a photoconducting molecule, and the DEH-doped polymer has been reported as a good candidate with excellent hole-mobility and photorefractivity. ${ }^{1 \cdot 1 ?}$ Simple amine-donor-substituted barbituric acid derivatives chromophore have been already well studied as a nonlinear optical chromophore with large hyperpolarizability and enhanced thermal stability. ${ }^{18}$

Figure 1 shows the DSC curves for H-C6-B as a<smiles>CCN(CC)c1ccc(C=O)c(O)c1</smiles>

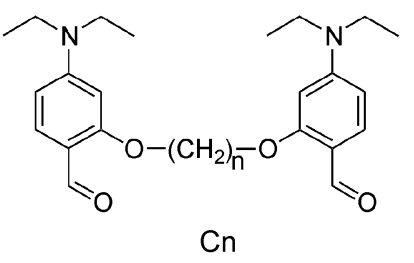<smiles>CCC(=O)OCc1ccccc1N(N)c1ccccc1</smiles>

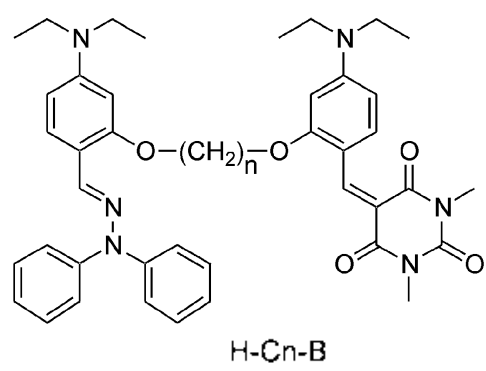<smiles>CCOC(C)C</smiles><smiles>CCN(CC)c1ccc(C=N)c(OCCCCOc2cc(N(CC)CC)ccc2C=O)c1</smiles><smiles>CN(c1ccccc1)c1ccccc1</smiles>

$\mathrm{H}$-Cn-ald 


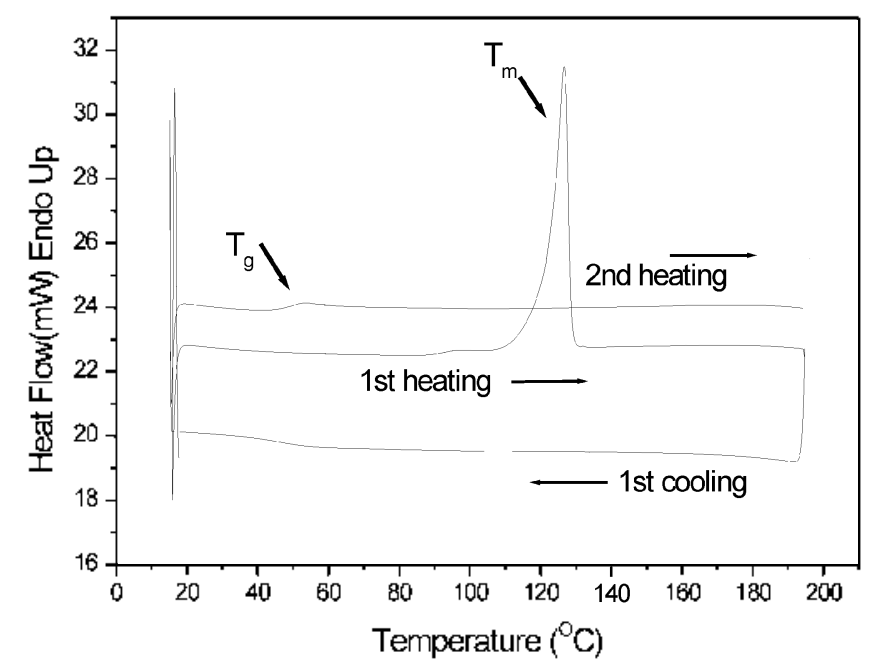

Figure 1. DSC curve of an amorphous molecule. HI-C6-B.

representative example. The sample was cooled below to melting temperature ( $\mathrm{T}_{\mathrm{m}}=126^{\circ} \mathrm{C}$ at the first heating). No recrystallization was observed at first cooling and the bifunctional molecules formed a glass with a glass transition temperature of $49^{\circ} \mathrm{C}$ at second heating. All coupled molecules (H-Cn-B) had melting points around $111-152^{\circ} \mathrm{C}$ at first heating. However, only the glass-transition temperature at second heating was determined to be around 26-58 ${ }^{\circ} \mathrm{C}$ without melting points. All H-Cn-B $(\mathrm{n}=3,4,5,6$, and 10) photorefractive bifunctional compounds formed stable glasses, i,e., no recrystallization occurred upon cooling at 10 ${ }^{\circ} \mathrm{C} / \mathrm{mim}$. All results of the thermal properties were summarized in Table 1. As the spacer group became longer ( $n=3,4,5,6$, and 10), the glass transition temperature gradually dropped, that is, the longer chain made the two moieties having more freedom to move relatively to each other. The longer linkage not only lowered the glass transition temperature of the samples but also allowed faster orientation of the chromophore. ${ }^{12}$ This observation indicates that these molecules were organic-glasses that formed a stable amorphous phase. Interestingly, all H-Cn-B (H-C3-B, H-C4-B, H-C5-B, H-C6-B, and H-C10-B) photorefractive bifunctional molecules could form amorphous organicglasses by themselves. H-C 10-B of the longest chain had the lowest glass transition temperature of $26^{\circ} \mathrm{C}$ among the coupled molecules, therefore, it was chosen to prepare for photorefractive composite in this study.

Table 1. Thermal properties of the coupled molecules

\begin{tabular}{|c|c|c|c|}
\hline & $\begin{array}{c}\mathrm{I}_{\text {it }}\left({ }^{\prime \prime} \mathrm{C}\right)^{\prime \prime} \\
\text { at lirst heating }\end{array}$ & $\begin{array}{c}\mathrm{T}_{\mathrm{y}}\left({ }^{\prime \prime} \mathrm{C}\right)^{\prime \prime} \\
\text { at second heating }\end{array}$ & $\begin{array}{c}\mathrm{I}_{\mathrm{tn}}\left({ }^{\circ} \mathrm{C}\right)^{\mathrm{t}} \\
\text { at second heating }\end{array}$ \\
\hline $11-(3-13$ & 152 & 58 & - \\
\hline $11-(4-13$ & 125 & 57 & - \\
\hline $11-C 5-13$ & 140 & 43 & - \\
\hline $11-(6-13$ & 126 & 49 & - \\
\hline $11-C)(0-13$ & 111 & 26 & - \\
\hline
\end{tabular}

"determined with a dillerential scanting calorimeter (DSC) at a heating rate of $10{ }^{\circ} \mathrm{C} / \mathrm{min}$ under nitrogen atmosphere

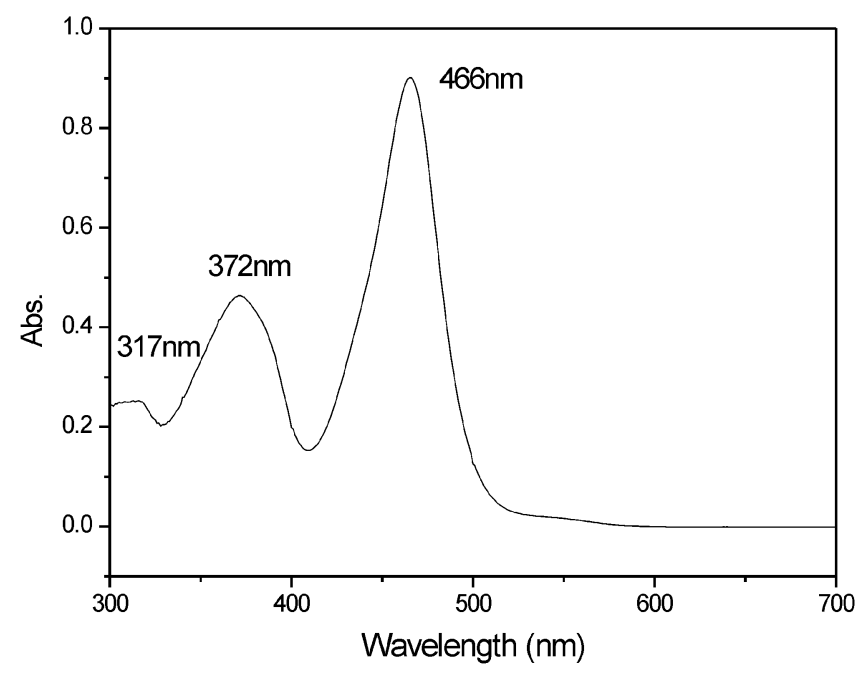

Figure 2. IJV-vis absorption spectum of a coupled molecule; $\mathbf{H}-$ C10-B.

The absorption maximum ( $\left.\lambda_{\text {rinax }}\right)$ of the coupled molecule, H-C10-B, was $466 \mathrm{~nm}$ as shown in Figure 2, which was virtually the same as that of the corresponding electro-optic chromophore, 5-(4-diethylamino-benzylidene)-1,3-dimethylpyrimidine-2,4,6-trione $\left(\lambda_{\max }=470 \mathrm{~nm}\right){ }^{18}$ This observation implies that the long aliphatic spacer did not give any influence on the electron conjugation of coupled molecules.

The photorefractive composite sample consisting of 89 wt $\%$ of H-C 10-B (bifunctional molecules), $10 \mathrm{wt} \%$ of BBP (plasticizer) and $1 \mathrm{wt} \%$ of $\mathrm{C}_{\text {6) }}$ (photosensitizer) [Figure 3] showed an excellent optical quality and no phase-separation or crystallization for a long time. The glass transition temperature of the composite was around $17^{\circ} \mathrm{C}$, which was determined by differential scanning calorimeter [Figure 4].

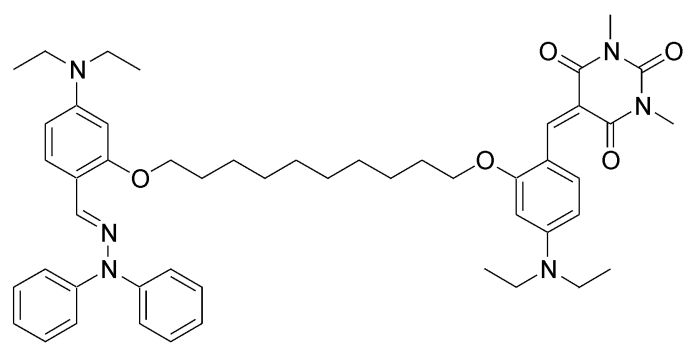

(a) H-C10-B
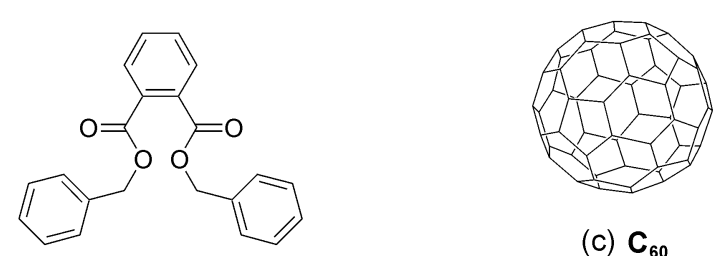

(c) $\mathrm{C}_{60}$

Figure 3. Chemical structures of components of photorefiactive composite: (a) 5-(4-dicthy lamino-2-\{ 10-[5-diethylamino-2-(diphonylbydrawomethyl)-phenoxy]-decyloxy;-hensy lidene)-1.3-dinethylpyrimidine-2,4,6-trione. H-C10-B: (b) plasticizer. BBP: (c) sensitizer. buckminsterfullerenc $\mathrm{C}_{60}$. 


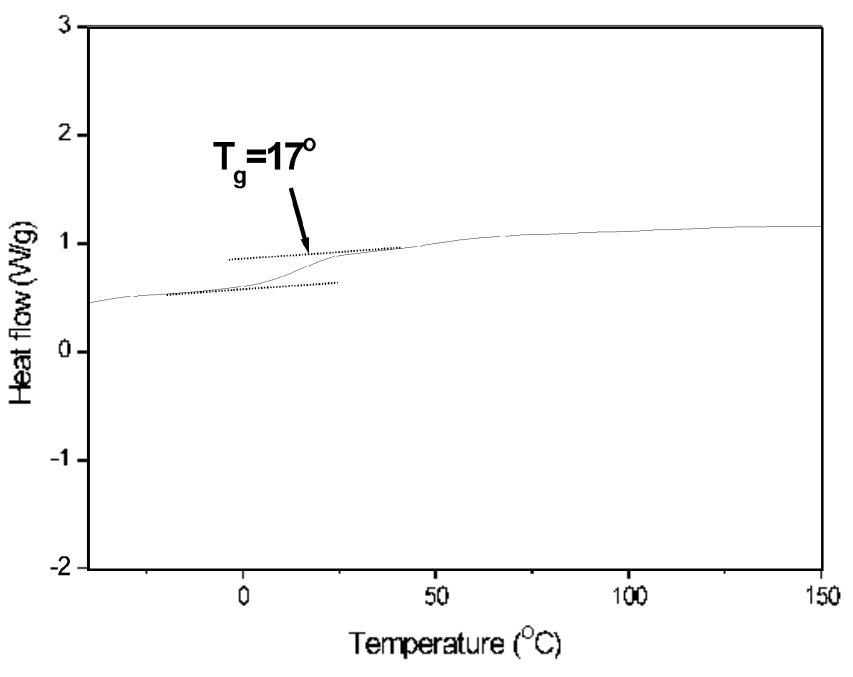

Figure 4. DSC thermogram: []-C10-B : BBP : $\mathbf{C}_{6,1}$ composite at a heating rate of $10^{\circ} \mathrm{C} / \mathrm{min}$ under nitrogen almosphere.

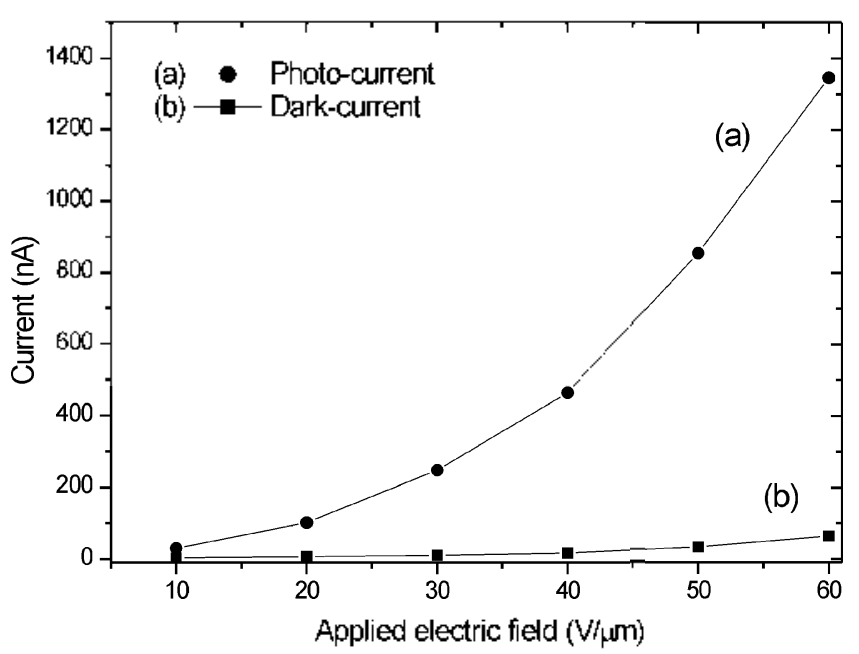

(A)

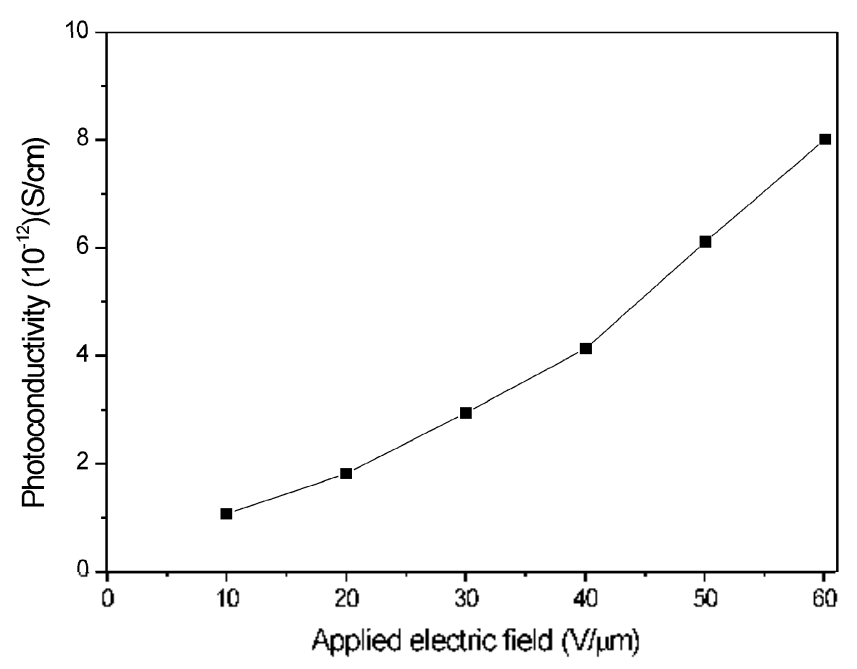

(B)

Figure 5. Photo-currentidark-current (A) and photoconductivity (B) of H-C10-B: BBP: $\mathrm{C}_{60}$ composite.

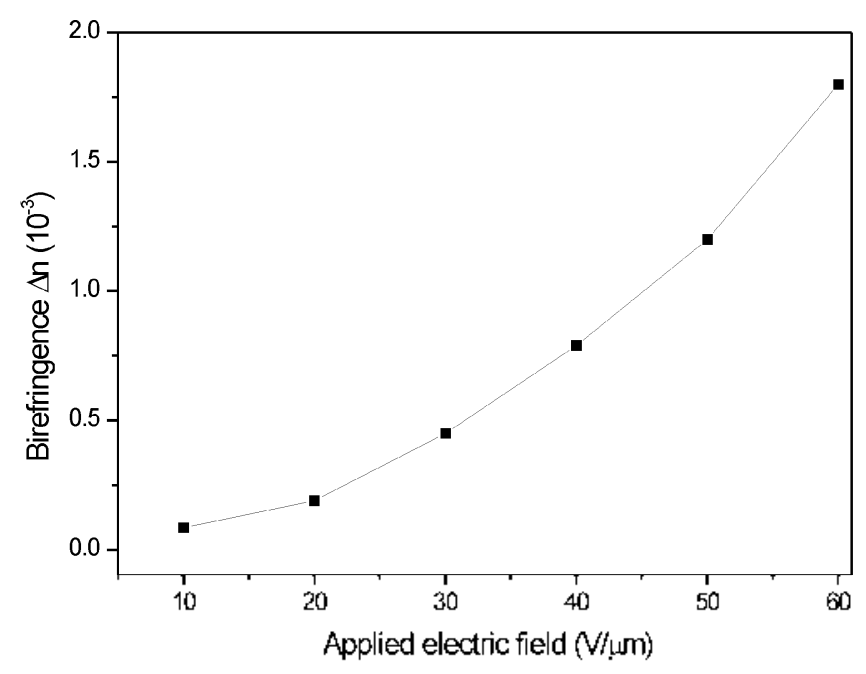

Figure 6. Llectric ficld induced birefringence of the composite. $\mathbf{H}$ C10-B : BBP : Cou. depending on the applicd electric ficld.

The photoconductivity of photorefractive material must be one of the important factors since it significantly influences the buildup time of photorefractive grating formation and magnitude of the space-charge field. The electric field dependence of the photocurrent is shown in Figure $5(\mathrm{~A})$. The photoconductivity of H-C10-B composite was measured to be $8.01 \times 10^{-12} \mathrm{~S} / \mathrm{cm}$ at the applied electric field of $60 \mathrm{~V} / 4 \mathrm{im}$. which was remarkably high photoconductivity [Figure 5 (B)]. It may be attributed to the superior hole-transporting ability of DEH.

Field-induced birefringence of the photorefractive composite was characterized by a transmission ellipsometric method at various applied electric fields. As shown in Figure 6. birefringence $(\Delta n)$ of the composite containing $89 \mathrm{wt} \%$ of H-C 10-B chromophore was quadratically increased with the applied electric fields. The composite showed an anisotropic property of $\Delta \mathrm{n}=1.8 \times 10^{-3}$ at $60 \mathrm{~V} / \mu \mathrm{m}$. This was relatively a lower value, compared to the other chromophore in hostguest composite system. The birefringence $(\Delta n)$ originates from the alignment of chromophores in noncentrosymmetric structures under the poling field. In the case of low $\mathrm{T}_{\mathrm{z}}$ photorefractive material, the modulation of refractive index $(\Delta n)$ is known to arise predominantly from reorientation of the optically nonlinear chromophore under the spatially modulated space-charge field. 'The orientational birefringence of the current composite is associated with the large $\mu^{2} \Delta \alpha$ of H-C10-B chromophore where $\Delta \alpha$ is the polarizability anisotropy and $\mu$ is the dipole moment.

The photorefractive property of H-C10-B: BBP: $\mathbf{C}_{60}$ composite was evaluated by diffraction efficiency, which was measured by a degenerate four wave mixing method. Figure 7 shows the applied electric field dependence of the steady-state diffraction efficiency. The maximum diffraction efficiency ( $\eta_{\max }$ ) of $50 \mu \mathrm{m}$-thick film was about $5 \%$ at $80 \mathrm{~V}$ / $\mu \mathrm{m}$. This $\eta_{\text {max }}$ was relatively low compared to the other hostguest composites, which might be responsible for the relatively low refractive index modulation $(\Delta n)$ of $c a .1 .8 \times$ $10^{-3.1^{10}}$ Also, according to the equation $\eta \propto\left(\gamma_{\mathrm{eff}} \mathrm{E}_{\mathrm{sc}}\right)^{2}$, the 


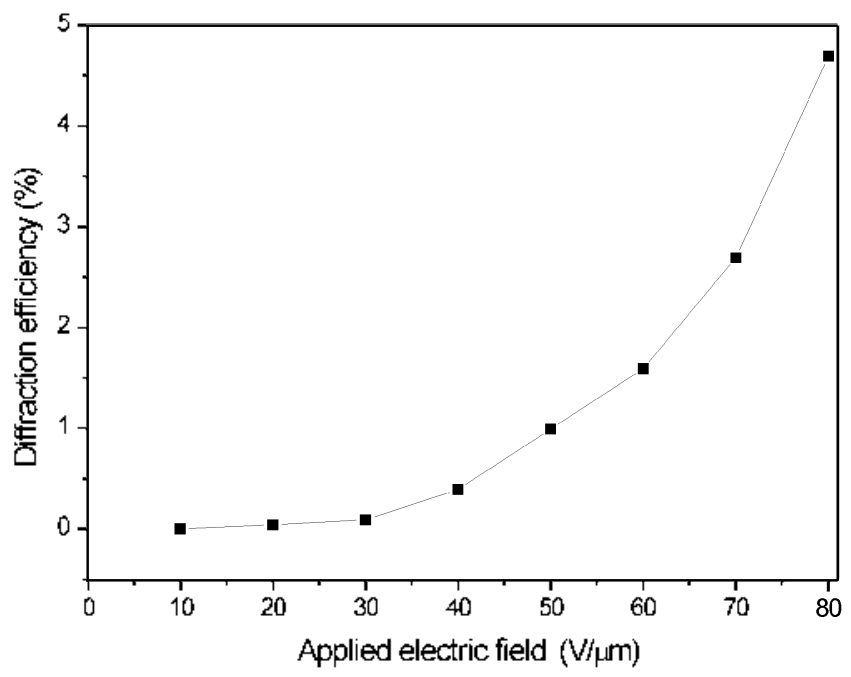

Figure 7. Steady-state difraction eflictency depending on electric ficld of H-C10-B : BBP : $\mathbf{C}_{60}$ composite.

relatively small values for the diffraction efficiency might be due to a small value of the space-charge field. ${ }^{21}$ The photorefractive behavior of this coupled-amorphous material system still seems to be limited by the chromophore reorientation despite of very high photoconductivity.

\section{Conclusions}

We synthesized a series of organic glassy molecules in order to improve the phase stability for photorefractive materials. The DEH unit, photoconducting moiety, and barbituric acid moiety, the electro-optical chromophore, were connected with a tlexible spacer. Depending on the aliphatic chains length, the glass transition temperature $\left(\mathrm{T}_{w}\right)$ gradually dropped as the longer chain gave the two terminal moieties more freedom to rotate or move relatively to each other. Also, DSC observation indicated the organic-glasses to form a stable amorphous phase. When doped with plasticizer BBP and sensitizer $\mathbf{C}_{60 .}$, it was determined to have a high photoconductivity of $8.01 \times 10^{-12} \mathrm{~S} / \mathrm{cm}$ but showed a moderate electro-optic behavior of $\Delta n=1.8 \times 10^{-3}$ at the applied electric field of $60 \mathrm{~V} / \mu \mathrm{m}$. The diffraction efficiency as a photorefractive behavior was just about $5 \%$ at $80 \mathrm{~V} / \mu \mathrm{m}$ despite of its high photoconductivity in this system.
Acknowledgment. This work was supported by a grant No. R01-2000-000-00338-0 from Korea Science \& Tingineering Foundation.

\section{References}

1. Moerner. W. F.: Silence. S. M. Chem. Rev. 1994. 94. 127.

2. (iünter, P.: H luignard, J.-P. In Photorefroctive Waterials and Their Application: Springer-Verlag: Berlin. vol.J. vol.Il (1988. vol.I). (1989. vol.JI).

3. Solnmar. L.: Webb. D. J.: Grumnet-Jepsen. A. The Phwsics and Apptications of Photoreffettive Materiats: Clarendon Press: Oxford. 1996.

4. Meerholy. K.: Volodin, B. I.: Sandalphon; Kippelen, B.: l'eyghambarian. N. Natme 1994.377. 497.

5. Hendrickx. E.: Herlocker. J.: Maldonaldo. J. L.: Marder. S. R.: Kippelon. B.: Persoons. A.: Peyghambarian. N. Appl. Phys. Lett. 1998.73 .1679

6. Wright. D.: Diaz-Garcia .M. A.: Casperson. J. D.: DeCluc. M.: Moerner, W. I.: Jivieg. R. I. Appl. Phys. Lett 1998. 73. 1490.

7. Chun. H.: Moon. L. K.: Shin. D. H.: Kim. N. Chem. Water 2001. 13. 2813.

8. Hohle. C.: Hoftnattn. U.: Schloter. S.: Thelakkat. M.: Strohricgl. P.: I Iaarer. D.: 7ilker. S. J. J. Mater: Chem. 1999, 9. 2205.

9. Wang. Q.: Wang. I.: Saddeh. II.: YII. I., Chem. Commun. 1999. 1689 .

10. Hofmann. 1.: Grasruck. M.: Leopold. A.: Schreiber. A.: Schloter. S.: Hohle. C.: Strohriegl. L': Haarer. D.: Zilker. S. J. J. Phys. (he'm. B 2000. 104. 3887.

11. Ogino. K.: Park. S. II.: Sato. II. Appl Phas Lett 1999. 7 . 3936.

12. He. M.: Tivieg. R.: (jubler, U..: Wright. D.: Moerner. W. L: Optical Materals 2002. 2/. 353.

13. Bitmer. R.: Daubler. I. K.: Neher. D.: Meerholz. K. Adu Mater: 1999. 11. 123

14. Schein. 1. B.: Borsunberger, P. М. Chem. P/ns, 1993, /77. 773 .

15. Sasaki. T.: (joto. M.: Jshikatwa Y.: Yoshimi. T. J. Phys. Chen. B 1999. 103. 1925.

16. Schein. L. B.: Rosenberg. A.: Rice. S. L. J. tppt. Phys. 1986. $60(12) .4287$

17. I.iphardt. M.: Goonesekera, $A$ : Jones. B. F.: Ducharmes. S.: Takacs. J. M.: 7.hang. I. Science 1994, 263, 367.

18. Moslan. C. R.: Twieg. R. J.: lee. V. Y.: Swanson. S. A.: Betterton. K. M.: Miller. R. D. J. Im. Chem. Soc. 1993. /15. 12599.

19. Kim. N. J.: Chun. H.: Moon. I. K.: Joo. W. J.: Kim. N. Bull. Koreun ('hem. Soc 2002. 23(4). 571.

20. Chun, 11: Kim, N. J.: Joo, W. J.: I Ian, J. W. Oh, C. II.: Kim, N. Sintheric Wetals 2002,129, 281.

21. Bolink. 11. J.: Arts. C.: Krasnikos. V. V: Malliaras. (i. Ci: Hadziioannou. G. Chem. Water. 1997. 9. 1407. 